\title{
Phytochemical Screening and Evaluation of the Diuretic Activity of Aqueous Methanol Extract from Aerial Parts of Mentha viridis Linn (Labiatae) in Albino Rats
}

\author{
Muhammad Majid Aziz', Najam Us Saqib², Naveed Akhtar ${ }^{1}$, Hafiz Muhammad \\ Asif $^{3 *}$, Muhammad Jamshaid ${ }^{4}$, Sabira Sultana ${ }^{1}$ and Kamran Bashir ${ }^{1}$ \\ ${ }^{1}$ Faculty of Pharmacy and Alternative Medicine, The Islamia University of Bahawalpur, ${ }^{2}$ Federal Inspector of Drugs, Cabinet \\ Division, Government of Pakistan, Islamabad, ${ }^{3}$ Department of Eastern Medicine \& Surgery, Faculty of Medical \& Health \\ Sciences, The University of Poonch, Rawalakot, AJ\&K, ${ }^{4}$ Faculty of Pharmacy, University of Central Punjab, Johar Town \\ Lahore, Pakistan
}

*For correspondence: Email: doctor.asif@yahoo.com; Tel: +92 3346911256

Received: 10 October 2013

Revised accepted: 18 April 2014

\begin{abstract}
Purpose: To evaluate the diuretic effect of the aqueous methanol extract of Mentha viridis Linn (Labiatae) in Albino rats.

Methods: The aqueous-methanol extract of Mentha viridis was administered to experimental rats at doses of 30, 50 and $100 \mathrm{mg} / \mathrm{kg}$, (i.p.) Furosemide $10 \mathrm{mg} / \mathrm{kg}$ (i.p.) and normal saline were used as reference drug and control, respectively. Diuretic effect was examined immediately after injecting the drugs and on an hourly basis by measuring the urine volume of the rats, sodium and potassium content and $\mathrm{pH}$ of the urine, comparing with that of the control. Preliminary phytochemical analysis of the extract was carried out to determine major constituents.

Results: The extract induced diuretic effects and induced electrolytes excretion in a dose- dependent manner in comparison with control. The extract $(100$ and $50 \mathrm{mg} / \mathrm{kg})$ significantly $(p<0.01)$ increased the volume of urine in comparison to control group. Excretion of potassium and sodium also significantly ( $p<$ 0.05) increased following extract administration. However, there was no significant change in the $\mathrm{pH}$ of urine samples of the extract-treated group compared with control. The diuretic effect of extract was comparable to that of the reference drug (furosemide). Phytochemical analysis revealed the presence of alkaloids, flavonoids, tannins and saponins.

Conclusion: The results indicate that the aqueous-methanol extract of Mentha viridis produced a diuretic effect that was comparable with that of the reference diuretic, furosemide, thus lending support for the traditional use of Mentha viridis as a diuretic agent.
\end{abstract}

Keywords: Diuretic activity, Potassium, Sodium, Urine volume, Mentha viridis, Furosemide, Phytochemical screening

Tropical Journal of Pharmaceutical Research is indexed by Science Citation Index (SciSearch), Scopus, International Pharmaceutical Abstract, Chemical Abstracts, Embase, Index Copernicus, EBSCO, African Index Medicus, JournalSeek, Journal Citation Reports/Science Edition, Directory of Open Access Journals (DOAJ), African Journal Online, Bioline International, Open-J-Gate and Pharmacy Abstracts

\section{INTRODUCTION}

It is thought that $64.0 \%$ of the world's population uses medicinal plants, either as a whole or in parts or in the form of infusions and decoctions [1]. In technologically developed countries such as the United States of America, $60 \%$ of the population use medicinal plants for therapeutic purpose for certain diseases while in Japan there is increasing demand for herbal drug preparations [2]. Human beings utilize many species of flora for food and medicine. It is also 
expected that the traditional and modern medicine uses about 50,000 - 70,000 species of plants [3]. By definition, drugs which used to increase urinary output and electrolyte excretion are called diuretics. These drugs mostly act on different parts of nephrons and increase urine volume. Diuretic can also increase the elimination of electrolytes [4]. These drugs are more useful in the treatment of edema, acute and chronic renal failure, and moderate hypertension. High ceiling and osmotic diuretic agents are used in several poisoning condition to increase excretion of poisoning agent [5]. Different types of diuretics like high, medium and low ceiling diuretics are used in the treatment of hypertension, congestive cardiac failure, liver cirrhosis and various kidney disorders [6]. Despite this, there is still need for extremely effective and less toxic diuretics in clinical practice. Medicinal plants are sources of several therapeutic agents. A majority of the population in Southeast Asian countries depend on herbal medicine for primary health care support [7].

Mentha viridis Linn (Labiatae) commonly known as spearmint, is a perennial, rhizomatous and herbaceous plant, growing $30-100 \mathrm{~cm}$ tall, having $5-9 \mathrm{~cm}$ long and $1.5-3 \mathrm{~cm}$ broad leaves. It possesses diuretic effects but until now, its diuretic activity has not been evaluated on an experimental basis. Mentha viridis is used traditionally as a relaxant, antispasmodic, and soothing agent in nausea and vomiting; it allays colics in children, fever, and stomach disorder, and acts as a diuretic [8]. The paste of its leaves is applied on wounds for healing [9]. Thus, this work was geared towards determining if there was a scientific basis for its traditional diuretic use by evaluating the diuretic activity of the aqueous methanol extract in albino rats.

\section{EXPERIMENTAL}

\section{Collection of plant material}

The fresh plant of Mentha viridis for the research work was collected in the month of May 2012 from the Abbot Abad city of Pakistan and was authenticated by Dr. Shazia Anjum, Director, Cholistan Institute of Desert Studies (CIDS), The Islamia University of Bahawalpur. A voucher specimen (MV-AP-06-12-042) was kept in the herbarium of Pharmacology Research Lab, Department of Pharmacy, The Islamia University of Bahawalpur.

\section{Preparation of crude extract}

The plant was washed with distilled water after extraneous substances had been removed.
Thereafter plant material was dried under shade at temperature between $21-30{ }^{\circ} \mathrm{C}$ for 30 days. The dried material was mechanically reduced to coarse powder and stored in an air tight container. $1000 \mathrm{~g}$ of powdered material of Mentha viridis was taken in beaker having 5 liter capacities and 2 liter of $70 \%$ methanol was added, macerated for $72 \mathrm{~h}$ with occasional shaking and stirring. The residues were extracted thrice with the same fresh solvent and extract combined. The macerated plant material was filtered through several layers of muslin cloth for coarse filtration. The filtrate was filtered through a whatman \# 1 filter paper. The filtered extract was concentrated under negative pressure (-760 $\mathrm{mmHg}$ ) at $40^{\circ} \mathrm{C}$ in a rotary evaporator (Heidolph Laborota 4000-efficient, Germany). The semisolid mass obtained indicate a yield of 14.12 $\%$, and was dried in an oven at $40^{\circ} \mathrm{C}[10,11]$.

\section{Preliminary phytochemical analysis}

A portion $(120 \mathrm{~g})$ of the concentrated extract of Mentha viridis was used for the preliminary phytochemical screening of alkaloids, saponins, flavanoids, and tannins by using standard methods [12,13].

\section{Dose preparation}

The aqueous methanol extract of Mentha viridis was dissolved in normal saline in a caped test tube, shacked and subjected to the Vortex mixture $(M y \operatorname{Lab} \otimes$, Korea) and then mixture is placed in Ultrasonic (Lc 30/H, Germany). Final dose was filtered by Filter paper (Grade -1) and its $\mathrm{pH}$ was measured at calibrated $\mathrm{pH}$ meter (Ino Lab WTW, Ph 720, Germany).

\section{Animal handling}

Adult albino rats of either sex, weighing 180-220 $\mathrm{g}$, were obtained from the animal house of the department of Pharmacy, The Islamia University of Bahawalpur. The animals were kept in polycarbonate cages $(47 \times 34 \times 18 \mathrm{~cm})$ and housed under standard conditions of temperature $\left(24 \pm 1{ }^{\circ} \mathrm{C}\right)$, humidity and dark light cycle $(12 \mathrm{~h} / 12 \mathrm{~h})$. They were fed with standard animal feed, containing chokar, chicken feed and dry milk in the ratio of 2:2:1. Study protocols and ethical issues were approved by Ethical committee and Board of Advance Studies and Research (BASR) of Faculty of Pharmacy, The Islamia University of Bahawalpur, Pakistan.

\section{Diuretic activity}

All animals were divided into five groups of six animals each. The control, group "A" received 
normal saline (10 $\mathrm{ml} / \mathrm{kg}$, i.p.), group "B" (reference group) was given furosemide (10 $\mathrm{mg} / \mathrm{kg}$, i.p.) as reference diuretic while group $\mathrm{C}$, $D$ and $E$ (test groups) were treated with the different doses of crude extract $(30,50$ and 100 $\mathrm{mg} / \mathrm{kg}$, i.p.) respectively. Immediately after injecting, the animals were placed separately in metabolic cages (Techniplast, Italy), specially designed to separate urine and faeces .Urine was collected in graduated vials and total volume was measured after $6 \mathrm{~h} \& 10 \mathrm{~h}$ interval and was closely monitored on hourly basis. The mean volume of urine expressed as $\mathrm{ml} / 100 \mathrm{~g}$ of body weight was calculated $[14,15]$.

\section{Measurement of urine output and electrolyte analysis}

Electrolyte $\left(\mathrm{Na}^{+}\right.$and $\left.\mathrm{K}^{+}\right)$concentrations and $\mathrm{pH}$ were calculated from the urine sample of each rat at the end of the experimental period and expressed as mequiv/100 g body weight. $\mathrm{Na}^{+}$ and $\mathrm{K}^{+}$concentrations were measured using a Sherwood Flame Photometer 410 Classical, UK $[16,17]$. The instrument was calibrated with standard solutions containing different concentrations of $\mathrm{Na}^{+}$and $\mathrm{K}^{+}$. The $\mathrm{pH}$ was measured with a pH meter (Ino Lab WTW, Ph 720 , Germany) on urine sample $[18,19]$.

\section{Statistical analysis}

SPSS (version 17.0) program was used to carry out Student t-test on the data and the results expressed as mean \pm SEM (standard error of mean). The results were considered statistically significant when $p<0.05$.

\section{RESULTS}

\section{Phytochemical analysis}

The phytochemical screening revealed the presence of saponins, alkaloids, flavonoids and tannins in Mentha viridis.

\section{Diuretic activity}

The aqueous methanol extract of the whole plant of Mentha viridis $(100 \mathrm{mg} / \mathrm{kg})$ showed marked diuresis $(3.74 \pm 0.41 \mathrm{ml})$ during the 6 th $\mathrm{h}$ versus control $(1.35 \pm 0.21 \mathrm{ml})$, compared with reference standard (furosemide, $4.05 \pm 0.34 \mathrm{ml})(p<0.05)$. The lower dose $(50 \mathrm{mg} / \mathrm{kg})$ of Mentha viridis extract also showed significant $(p<0.05)$ diuretic activity $(3.38 \pm 0.51 \mathrm{ml})$ versus control $(1.35 \pm$ $0.21)$. The urine output at 8 th hour and 10th $\mathrm{h}$ was also significant $(p<0.01)$ (Table 1). The diuretic index of Mentha viridis (30,50 and 100 $\mathrm{mg} / \mathrm{kg}$ ) was recorded as $1.38,2.5$ and 2.7 at 6 th hour while it was $1.35,1.5$ and 1.5 at the 10th hour, respectively, (Table 2 ).

Table 2: Diuretic index of Mentha viridis extract in rats

\begin{tabular}{lcc}
\hline Treatment & \multicolumn{2}{c}{ Diuretic index } \\
\cline { 2 - 3 } & $\mathbf{6} \boldsymbol{h}$ & $\mathbf{1 0} \boldsymbol{h}$ \\
MV $30 \mathrm{mg} / \mathrm{kg}$ & 1.38 & 1.35 \\
$\mathrm{MV} 50 \mathrm{mg} / \mathrm{kg}$ & 2.5 & 1.5 \\
MV $100 \mathrm{mg} / \mathrm{kg}$ & 2.7 & 1.5 \\
Furo $10 \mathrm{mg} / \mathrm{kg}$ & 2.8 & 1.6 \\
\hline
\end{tabular}

\section{Effect on urinary electrolyte excretion}

The effect of furosemide $(10 \mathrm{mg} / \mathrm{kg})$ and the extract of Mentha viridis $(100 \mathrm{mg} / \mathrm{kg})$ on electrolyte $\left(\mathrm{Na}^{+}\right.$and $\left.\mathrm{K}^{+}\right)$excretion in the $6 \mathrm{~h}$ urine are presented in Table 3. The plant extract significantly enhanced the excretion of the electrolytes $(p<0.05)$ which was comparable to that of furosemide. $\mathrm{Na}^{+}$concentration of the test extract was $539.50 \pm 0.29 \mu \mathrm{mole} / \mathrm{kg}$ against control which was $465.50 \pm 0.14 \mu \mathrm{mole} / \mathrm{kg}$.

$\mathrm{K}+$ concentration of extract was $45.99 \pm 0.11$ $\mu$ Mole $/ \mathrm{kg}$, while that of the control was $20.13 \pm$ $0.25 \mu \mathrm{Mole} / \mathrm{kg}$. The results when compared indicates that the electrolytic concentration was significantly $(p<0.05)$ more than that of the control and comparable to furosemide.

Table 1: Effect of Mentha viridis extract on urine volume $(\mathrm{ml} / 100 \mathrm{mg})$ of albino rats $(\mathrm{n}=5)$

\begin{tabular}{lllllll}
\hline Treatment & $\mathbf{1}^{\text {st }}$ hour & $\mathbf{2}^{\text {nd }}$ hour & $\mathbf{4}^{\text {th }}$ hour & $\mathbf{6}^{\text {th }}$ hour & $\mathbf{8}^{\text {th }}$ hour & $\mathbf{1 0}^{\text {th }}$ hour \\
\hline Saline $10 \mathrm{ml} / \mathrm{kg}$ & $0 \pm 0$ & $0.33 \pm 0.21$ & $0.76 \pm 0.22$ & $1.35 \pm 0.21$ & $2.19 \pm 0.21$ & $2.96 \pm 0.16$ \\
MV $30 \mathrm{mg} / \mathrm{kg}$ & $0.26 \pm 0$ & $0.44 \pm 0.19$ & $0.98 \pm 0.14$ & $1.87 \pm 0.18$ & $3.20 \pm 0.37^{*}$ & $4.01 \pm 0.40^{* *}$ \\
MV $50 \mathrm{mg} / \mathrm{kg}$ & $0.71 \pm 0$ & $1.42 \pm 0.19$ & $1.87 \pm 0.37$ & $3.38 \pm 0.51^{*}$ & $4.05 \pm 0.60^{* *}$ & $4.45 \pm 0.62^{* *}$ \\
MV $100 \mathrm{mg} / \mathrm{kg}$ & $0.98 \pm 0$ & $1.15 \pm 0.18$ & $2.67 \pm 0.37$ & $3.74 \pm 0.41^{*}$ & $4.45 \pm 0.60^{* *}$ & $4.45 \pm 0.68^{* *}$ \\
Furo $10 \mathrm{mg} / \mathrm{kg}$ & $1.80 \pm 0$ & $1.97 \pm 0.21$ & $3.24 \pm 0^{*}$ & $4.05 \pm 0.34^{* *}$ & $5.22 \pm 0.33^{* *}$ & $5.94 \pm 0.44^{* *}$
\end{tabular}

Furo $=$ furosemide; $p<0.05$ significantly $\left({ }^{*}\right)$ and $p<0.01$ significantly $\left(^{* *}\right)$ different from the control 
Table 3: Concentration of sodium and potassium in urine of rats treated with Mentha viridis extract

\begin{tabular}{lllll}
\hline Treatment & Sodium $(\mathbf{p p m})$ & Potassium $(\mathbf{p p m})$ & \multicolumn{2}{c}{ Lipschitz value } \\
\cline { 3 - 4 } & & & $\mathbf{6 ~ h}$ & $\mathbf{1 0 ~} \mathbf{~}$ \\
\hline Normal saline & $488.5 \pm 0.39$ & $25.18 \pm 0.18$ & 0.43 & 0.52 \\
Extract $30 \mathrm{mg} / \mathrm{kg}$ & $511.7 \pm 0.49$ & $34.56 \pm 0.19$ & 0.50 & 0.53 \\
Extract $50 \mathrm{mg} / \mathrm{kg}$ & $530.1 \pm 0.38^{*}$ & $44.17 \pm 0.32^{*}$ & 0.52 & 0.53 \\
Extract $100 \mathrm{mg} / \mathrm{kg}$ & $539.5 \pm 0.29^{* *}$ & $45.99 \pm 0.11^{* *}$ & \\
Furosemide $10 \mathrm{mg} / \mathrm{kg}$ & $566.9 \pm 0.02$ & $47.99 \pm 0.09$ & & \\
${ }^{*} p<0.05$ and ${ }^{* *} p<0.01$ when compared with control & &
\end{tabular}

\section{pH urine samples}

The $\mathrm{pH}$ of urine samples following treatment with Mentha viridis extract doses of 30,50 and 100 $\mathrm{mg} / \mathrm{kg}$ was $6.38,6.78$ and 6.89 respectively. The change in mean $\mathrm{pH}$ of urine after administration of Mentha viridis extract at 30,50 and $100 \mathrm{mg} / \mathrm{kg}$ was $6.89,6.76$ and 6.94 , respectively. The change in urinary $\mathrm{pH}$ was insignificant.

\section{DISCUSSION}

Current study was carried out for scientific authentication of the plant, Mentha viridis used traditionally for diuretic purpose. Mentha viridis is known to possess antiemetic, antispasmodic, carminative, diuretic, restorative, stimulant and stomachic properties [20]. As diuretic therapy may lead to a number of life threatening electrolytic disorder and toxicities, so safety profile studies are carried out on various doses of extract. This amplifies the heterogenous array of diuretic curatives available for safe and effective treatment of edema and cardiovascular diseases [21].

For evaluation of the diuretic activity, Mentha viridis was selected. After the extractions, extract was phytochemically screened. The phytochemical analysis showed the presence of active phytochemical groups such as flavonoids, terpenoids and saponins and the previous studies showed that these groups are responsible for diuretic activity by exerting favorable effects on physiological processes of the kidney such as by increasing potassium sparing capacity, binding with adenosine A1 receptor associated with diuretic activity or possibly by inhibiting tubular reabsorption of water and accompanying anions [22,23].

The effect may also be produced by the stimulation of regional blood flow or initial vasodilation [24]. Excretion of electrolytes indicates that the plant can be used for the treatment of edema, congestive heart failure \& hypertension [25].
Potassium contents in the urine samples were observed, although low. The potassium loss that occurs with many diuretics may lead to hypokalemia. For this reason, generally potassium-sparing diuretics are recommended [26]. In the present study, aqueous methanol extract showed a minimal level of potassium in urine which may increase risk of hypokalemia and although this amount is low, its potassium sparing capability has to be investigated. Natiuretic effects found, was high in urine samples. The increased sodium and water excretion activity also provides strong basis for its anti-hypertensive action [27]. The regulation of sodium and potassium is intimately related to renal control of acid-base balance [28]. The data was found statistically significant when compared with normal control. This also indicates that the component of Mentha viridis responsible for diuresis has shorter half life and quick onset of action. The results obtained in this study provide a quantitative basis to explain the traditional folkloric use of Mentha viridis as a diuretic agent.; The extract possesses marked diuretic activity therefore supporting its ethno-pharmacological use as a diuretic. Further phytochemical and pharmacodynamic investigations are required to investigate the active constituents responsible for the activity and to understand the exact mechanism of diuretic effect exhibited by aqueous methanol extract of Mentha viridis.

\section{CONCLUSION}

The aqueous methanol extract of Mentha viridis exhibits significant diuretic activity comparable to that of furosemide, and thus this lends some support for the use of the plant in traditional medicine as a diuretic.

\section{ACKNOWLEDGEMENT}

The authors would like to express sincere thanks to Dean and Chairman of University College of Conventional Medicine, Faculty of Pharmacy and Alternative Medicine for providing support and necessary facilities to carry out this work. 


\section{REFERENCES}

1. Balunas MJ, Kinghorn AD. Drug discovery from medicinal plants: Life Sci. 2005; 78: 431-441.

2. Duke JA. "Returning to our Medicinal Roots". Mother Earth News. 2000. 26-33

3. Maykel P, Maria AB, Francisco JM, Mario LS, Evangelina $M$, Emoe B. Ethnopharmacological and preclinical study of diuretic activity in medicinal and food plants used by Cuban population. Emir. J. Food Agric. 2011; 23(3): 214-221.

4. Bhavna M, Rani S. Screening ofAchyranthus aspera, Acorus calamus,Caesalpinia crista for diuretic activity. Blonano Frontier. 2006; 2(1): 53-54.

5. Samiulla DS, Harish MS. Effect of Nr-AG-I and NR-AG-II (Polyherbal Formulation) on diuretic activity in rats. Indian J Pharmacol. 2000; 32: 112-113.

6. Singh RG, Singh RP, Usha KP. Experimental evaluation of diuretic action of herbal drug (Tribulus terrestris Linn) on albino rats. J Res Edu Ind Med. 1991; 3:1921.

7. Umang P, Mukul K, Vaishali U, Ashok B. Evaluation of diuretic activity of aqueous and methanol etract of Lepidium sativum garden cress (Cruciferae) in rats. Trop J Pharm Res. 2009; 8(3): 215-219.

8. William CMD. The physio-medical dispensatory. West Sixth-street, Boulder, Colorado. Medical Herbalism; 1869. pp. 362-363.

9. Sandeep BP. Traditional uses of plants for wound healing in the Sangli district, Maharashtra. Int J Pharm Tech Res. 2009; 1(3): 876-878.

10. Patel U, Kulkarni M, Undale V, Bhosale A. Evaluation of diuretic activity of aqueous and methanol extracts of Lepidium sativum Garden cress (Cruciferae) in rats. Trop J Pharm Res. 2009; 8(3): 215-219.

11. Jabeen $Q$, Bashir S, Lyoussi B, Gilani AH. Coriander fruit exhibits gut modulatory, blood pressure lowering and diuretic activities. J Ethnopharmacol. 2009; 123: 123130.

12. Gilani, $A H$, Khan $A U$, Jabeen $Q$, Subhan $F$, Ghafar $R$. Antispasmodic and blood pressure lowering effects of valeriana wallichii are mediated through $k+$ channel activation. J Ethnopharmacol .2005; 100: 347-352.

13. Tona L, Kambu K, Ngimbi N, Cimanga K, Vliellnck AJ Anti-amoebic and phytochemical screening of some congolese medicinal plants. J Ethnopharmacol. 1998; 61: 57-65.

14. Ratnasooriya $M D$, Pieris KP, Samaratunga U, Jayakody $J R$. Diuretic activity of Spilanthes acmella flowers in rats. J Ethnopharmacol. 2004; 91(2-3): 317-320.
15. Gilani $A H$, Jabeen $Q$, Kahn $A U$, Shah AJ. Gut Modulatory, Blood pressure lowering, diuretic and sedative activities of cardamom. J Ethnopharmacol. 2008; 115: 463-472.

16. Jabeen $Q$, Bashir S, Lyoussi B, Gilani AH. Coriander fruit exhibits gut modulatory, blood pressure lowering and diuretic activities. J Ethnopharmacol. 2009; 123: 123130.

17. Abdala $S$, Martin-Herrera $D$, Benjumea $D$, Perez-Paz $P$. Diuretic activity of Smilax canariensis, an endemic canary island species. J Ethnopharmacol. 2008; 119:12-16.

18. Overman RR, Davis AK. The application of flame photometry to sodium and potassium determination in biological fluids. J Biol Chem. 1947; 163: 429-435.

19. Jesupillai M, Jasmine S, Palanivelu M. Diuretic activity of leaves of Erythrina indica L. Int J Green Pharm. 2008; 218-219.

20. Senthil K. Direct shoot regeneration from inter nodal explants of Mentha viridis L. Int J Pharm Sci Res. 2012; 3(4): 904-906.

21. Maghrani M, Zeggwagh N, Haloui M, Eddouks M. Acute diuretic effect of Retama raetam in normal rates. $J$ Ethnopharmacol. 2005; 99: 31-35.

22. Sood AR, Bajpai A, Digits M. Pharmacological and biological studies on saponins. Indian J Pharmacol. 1985; 17(3): 178-179.

23. Rizvi SH, Shoeb A, Kapil RS, Satya PP. Two diuretic triterpenoids from Antiderma menasu. Phytochem.1980; 19 (11): 2409-2410.

24. Bevevino LH, Vieira FSA, Cassola AC, Sanioto SML. Effects of crude extract of roots of Bredemeysra floribunda Wild. on arterial blood pressure and renal excretion in the rats. J Ethnopharmacol. 1994; 43: 197-201.

25. Vogel HG. Drug discovery and evaluation. Pharmacological assays, 2nd edn, Berlin: Springer Verlag. 2002; 323-326.

26. Sturat, IF. Human Physiology. Wm. C. Brown Publishers, Dubuque, Lowa, 2nd edn: 2002; pp. 500-503, 508.

27. Jouad H, Haloui M, Rhiouani H, El Hilaly J, Eddouks M. Ethnobotanical survey of medicinal plants used for the treatment of diabetes, cardiac and renal diseases in the North centre region of Morocco (FezBoulemane). J Ethnopharmacol. 2001; 77: 175-182

28. Sharma V, Verma $P$. Convolvulus arvensis $L$. root extracts increase urine output and electrolytes in rats. Int J Pharma Res Dev. 2011; 3(23): 193-197. 